\title{
$\mathrm{HaCaT}$ 세포에서 $\mathrm{TNF}-\alpha$ 에 의해 유도되는 $\mathrm{MMP}-1$ 에 대한 Gallic Aicd의 저해 효과
}

\author{
김범호 ${ }^{*}$
}

${ }^{1}$ 원광대학교 한의학전문대학원 한약자원개발학과

\section{Inhibitory Effect of Gallic Aicd on TNF- $\alpha$-induced matrix metalloproteinase-1 (MMP-1) in HaCaT Cells}

\author{
Pom-Ho Kim $^{1^{*}}$ \\ ${ }^{1}$ Department of Herbal Resources, Professional Graduate School of Oriental Medicine, \\ Wonkwang University
}

\begin{abstract}
요 약 본 연구는 항주름 소재를 개발하기 위해서 목단피로부터 gallic acid (GA)를 분리하여 항산화능을 측정하였고, $\mathrm{HaCaT}$ 세포에서 세포독성을 측정하였다. 또한 $\mathrm{HaCaT}$ 세포에서 tumor necrosis factor alpha (TNF-a)에 의해 유도되는 matrix metalloproteinase-1 (MMP-1) mRNA 발현, protein 발현, 분비에 대한 GA의 영향을 관찰하였다. 결과로써 GA는 30 $\mu \mathrm{g} / \mathrm{mL}$ 의 $\mathrm{IC}_{50}$ 과 함께 항산화능을 나타내었고, 그것의 항산화능은 합성항산화제인 butylated hydroxyanisol (BHA)보다 높았 다. $\mathrm{GA}$ 는 $\mathrm{HaCaT}$ 세포에서 고농도인 $200 \mathrm{\mu g} / \mathrm{mL}$ 처리시 약한 세포독성을 나타내었다. 또한 $\mathrm{HaCaT}$ 세포에서 $\mathrm{TNF}-\mathrm{a}(10$ $\mathrm{ng} / \mathrm{mL}$ )의 처리에 의해 증가된 MMP-1의 mRNA 발현, protein 발현, 분비는 GA의 처리에 의해 농도 의존적으로 유의적인 감소를 나타내었다 $(p<0.05)$. 그러므로 GA는 항산화 효과와 TNF- $a$ 로부터 유도되는 MMP- 1 의 발현을 저해함으로써 피부 주름을 개선할 수 있는 주름개선제로서의 활용가능성을 확인하였다.
\end{abstract}

\begin{abstract}
In order to develop anti-wrinkle agent, we measured the anti-oxidative activity of gallic acid (GA) from Paeonia suffruticosa Andrews and investigated its cytotoxicity in HaCaT cells and then investigated its effect on tumor necrosis factor alpha (TNF-a)-induced matrix metalloproteinase-1 (MMP-1) mRNA, protein expressions and secretion in same cells. GA showed anti-oxidative activity with $\mathrm{IC}_{50}$ of $30 \mu \mathrm{g} / \mathrm{mL}$ and its activity was higher than that of butylated hydroxyanisol (BHA). GA showed weak cytotoxicity with high concentration $(200 \mu \mathrm{g} / \mathrm{mL})$ in $\mathrm{HaCaT}$ cells. MMP-1 mRNA, protein expression and secretion induced by tumor necrosis factor alpha (TNF-a) in HaCaT cells were significantly decreased by treatment of GA with dose-dependent manner $(p<0.05)$. Therefore, our findings suggest that GA can be useful as an active ingredient for cosmeceuticals of anti-wrinkle effects.
\end{abstract}

Key Words : Anti-wrinkle effects, Gallic acid, Matrix metalloproteinase-1 (MMP-1), Paeonia suffruticosa

\section{1. 서론}

피부는 인체의 $16 \%$ 를 차지하고 있으며, 외부환경과 직접적으로 접해 있어 온도, 습도 및 자외선 등과 같은 외부 유해인자들로 부터 인체를 보호하는 중요한 역할을 하고 있다[1]. 피부는 외측으로부터 표피, 진피, 피하조직 으로 구성되어 있으며, 진피는 표피의 아래에 있는 결합
조직으로 이루어지는 조직으로써 세포외 공간이 많으며, 세포외기질 (extracellular amtrix)이라 불리는 거대분자의 망상 구조에 의해 채워져 있다[2].

피부노화는 지속적인 자외선 (ultraviolet radiation, UV) 노출에 의해 일어나는 광노화와 생리학적 노화에 의 한 내인성 노화로 구분되며, 특히 자외선 노출에 의한 광 노화가 주된 원인이 되고 있다 [3]. 피부 노화는 피부 진
${ }^{*}$ Corresponding Author : Pom-Ho Kim(Wonkwang Univ.)

Tel: +82-10-2300-8592 email: biopalpal@naver.com

Received October 21, $2013 \quad$ Revised October 31, 2013
Accepted November 7, 2013 
피층에 존재하는 세포외기질의 구조적인 변화로 발생하 게 되는데 피부 진피조직의 교원질 중 피부 탄력 성분 단 백질인 콜라겐의 현저한 감소에 의해서라고 할 수 있다 [4-6]. 세포외기질 분해는 matrix metalloproteinases (MMPs)에 의해 일어나며, 특히, MMP-1에 의해서 콜라 겐의 분해가 발생하여 주름, 잔주름 등이 발생 한다[7,8]. 따라서 피부노화와 주름의 개선에 있어 reactive oxygen species (ROS)와 같은 활성산소를 제거하는 항산화 물질 이나 콜라게네이즈의 작용을 억제하고 콜라겐의 합성을 촉진 시키는 소재의 발굴이 중요하다.

많은 연구들은 어떠한 부작용 없이 사람 피부를 위한 높은 생물학적 기능을 갖는 자연적인 물질들을 찾는데 집중해오고 있다. Alpha-naphthoflavone은 UVB로 조사된 사람 섬유아세포에서 항노화 효과를 나타낸다고 보고하 였다[9]. 사람 피부에서 감나무 잎 [persimmon leaf (Diospyros kaki folium)으로부터 분리한 폴리페놀의 주름 개선 효과를 보고하였다 [10]. 또한 In vivo에서 콜라겐 같은 펩타이드들 (collagen-like peptide)은 피부에 적용했 을 때 괄목할 만한 주름 개선 효과를 나타낸다고 보고하 였다[11].

미나리아재비과 (Ranunculaceae)에 속하는 목단피 (Paeonia suffruticosa Andrews)는 항염증, 감염저해, 항고 혈압, 항당뇨, 신경보호 효과가 있는 것으로 알려져 있다 [12-15]. 그러나 목단피의 MMP-1저해 효과에 대해서는 알려져 있지 않다. 따라서 본 연구에서는 목단피로부터 항산화능을 갖는 gallic acid를 분리하고 이것의 MMP-1 mRNA expression, secretion에 대한 영향을 관찰하여 주 름 개선 화장품 소재로서의 개발 가능성을 검토하였다.

\section{2. 재료 및 방법}

\section{1 실험약재 및 시약, 기기}

본 실험에 사용된 한약재 목단피는 전남 강진에서 생 산된 제품을 서울의 보은한약건재약업사에서 구입하여 정선된 것을 사용하였다. 항생제 용액 (Antibioticantimycotic solution), 혈청 [fetal bovine serum (FBS)], 배 지 [Dulbecco's modified Eagle' s medium (DMEM)], 트립신-이디티에이 (trypsin-EDTA)는 Gibco BRL (Grand Island, NY)에서 구입하여 사용하였다. 세포배양 플레이 트 (Tissue culture plates)들은 Falcon (BD Biosciences, Franklin Lakes, NJ)에서 구입하여 사용하였다. 셀포로다 민 B [Sulforhodamine B (SRB)]와 Butylated hydroxyanisol (BHA), 1, 1-diphenyl-2-picryl-hydrazyl $(\mathrm{DPPH})$ 은 시그마 [Sigma-Aldrich (St. Louis, MO)]에서
구입하여 사용하였다. 모든 다른 시약들은 높은 등급의 것을 사용하였다.

핵자기공명스펙트럼 (NMR spectra)은 Varian Germini 200 spectrometer에서 ${ }^{1} \mathrm{H}-\mathrm{NMR}$ 에 대해 $400 \mathrm{MHz}$ 에서 분 석하였으며, Varian VXR-30 spectrometer에서 ${ }^{13} \mathrm{C}-\mathrm{NMR}$ 에 대해 $100 \mathrm{MHz}$ 에서 분석하였다. 화학적 이동 (Chemical shifts)은 내부 기준으로써 tetramethylsilane (TMS)를 사용하면서 $\delta$ 스케일로 $\mathrm{ppm}$ 단위로 기록하였 다. 질량 스펙트럼 (Mass spectra)은 electrospray ionization mass spectrometry (ESI-MS, Fisons VG Quattro 400 mass spectrometer, USA)에서 분석하였다. 실리카겔 60 [Silica gel 60 (0.063-0.200 mm, Merck, Darmstadt, Germany)]은 column chromatography에 사용 되어졌다. 미리 코팅된 실리카겔 플레이트[Pre-coated silica gel plates (Silica gel $60 \mathrm{~F} 254,0.20 \mathrm{~mm}$, Merck)]는 박층 크로마토그래피 [thin layer chromatography (TLC)] 분석에 사용되어졌다. 액체크로마토그래피 [high-performance liquid chromatography (HPLC); SCL-10 AVP, Shimadzu, Kyoto, Japan]는 활성 성분을 분 리하기 위해 사용되어졌다.

\section{2 약재 추출과 분리}

분쇄한 목단피 $1 \mathrm{~kg}$ 을 $70 \%$ 에탄올 $2 \mathrm{~L}$ 에 침지하여 실 온에서 3일에 한 번씩 2회 추출하여 여과한 후 감압 농축 하여 에탄올 추출물 $75 \mathrm{~g}$ 을 얻었다. 이것을 hexane, ethyl acetate, butanol 순으로 분획하여 각 분획물 $11 \mathrm{~g}, 25 \mathrm{~g}$, $19 \mathrm{~g}$ 을 얻었다. 목단피 에탄올 추출물 및 이들 용매 분획 물의 항산화활성을 검색한 결과 butanol 분획물은 $\mathrm{IC}_{50}$ 값 이 $13 \mu \mathrm{g} / \mathrm{mL}$ 로써 강한 DPPH radical 소거활성을 나타내 어 이 butanol분획물을 메탄올-물 $[\mathrm{MeOH}-$ water $(0: 1 \rightarrow$ 1:0)]을 이동상으로 하여 $\mathrm{YMC}$ gel column chromatography를 실시하여 8개의 소분획 (Fr. 1- Fr. 8) 을 얻었다. 각각의 소분획에 대하여 DPPH radical 소거활 성을 검색한 결과, Fr. 2 분획 $(3.8 \mathrm{~g}$ )이 $50 \mu \mathrm{g} / \mathrm{mL}$ 의 농도 에서 $50 \%$ 이상 강한 radical 소거활성을 나타내었으므로, 이것을 클로로포름-메탄올-물 [ $\mathrm{CHCl}_{3}-\mathrm{MeOH}-\mathrm{H}_{2} \mathrm{O}$ (70:30:5)] 로 silicagel column chromatography하여 5개의 소분획 (Fr. 2-1- Fr. 2-5)을 얻었고, 이중 Fr. 2-3 (1.9 g)에 대하여 prep. HPLC [column: YMC-Pack ODS-A $(20 * 250 \mathrm{~mm}$, YMC), mobile phase; $\mathrm{CH}_{3} \mathrm{CN}-\mathrm{H}_{2} \mathrm{O}$ (20:80), flow rate: 3 $\mathrm{ml} / \mathrm{min}, 254 \mathrm{~nm}$ 를 실시하여 다시 2개의 분획 (Fr. 2-3-1 and Fr.2-3-2)으로 나누었다. Fr. 2-3-1 (0.8 g)을 이동상 $10 \%$ 아세토나이트릴 $\left(\mathrm{CH}_{3} \mathrm{CN}\right)$ 로 prep. HPLC[column: YMC-Pack ODS-A $(20 \times 250 \mathrm{~mm}$, YMC $)$, mobile phase; $\mathrm{CH}_{3} \mathrm{CN}-\mathrm{H}_{2} \mathrm{O}$ (10:90), flow rate: $3 \mathrm{~mL} / \mathrm{min}, 254 \mathrm{~nm}$ ]를 실 
시하여 분리한 결과, tR이 12.42 분 정도에 나타나는 백색 의 무정형 분말 $0.046 \mathrm{~g}$ 을 얻었다[Fig. 1].

\section{3 세포배양}

$\mathrm{DMEM}$ 배지에 혈청 $10 \%$, 항생제 $0.01 \%$ 를 첨가한 배 지에서 $37^{\circ} \mathrm{C}$ 온도조건에서 증식시켜 사용하였다.

\section{4 세포독성}

세포독성은 SRB 방법에 의해 평가하였고[16], 결과는 대조군의 \%로 계산되어졌다.

\section{5 항산화 활성 측정}

항산화 활성은 $\mathrm{DPPH}$ 방법[17]에 의해 평가하였고 결 과는 DPPH radical을 $50 \%$ 소거시키는 시료의 농도를 $\mathrm{IC}_{50}$ 으로 하여 평가하였다.

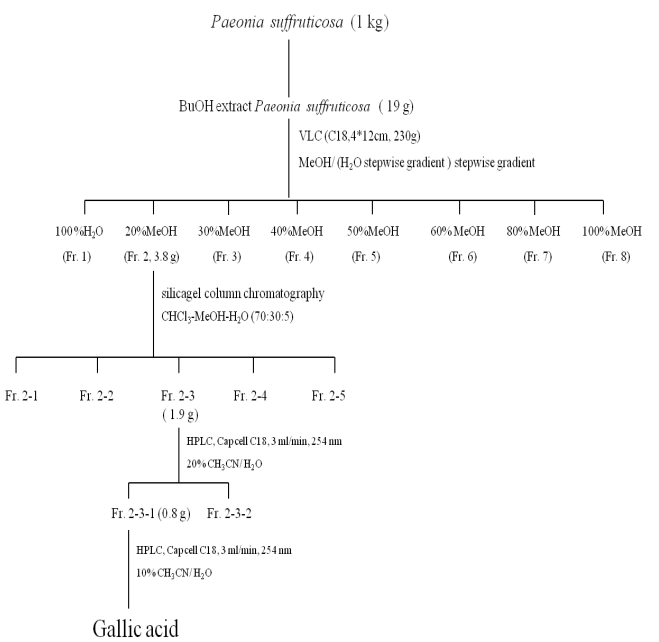

[Fig. 1] Procedures of solvent partitions for ethanolic extract of Paeonia suffruticosa.

음성대조군은 시료대신 에탄올을 동량 첨가하여 실험 하였고, 양성대조군으로는 합성항산화제인 butylated hydroxyanisole (BHA)을 이용하여 동일한 방법으로 실시 하였다.

\subsection{RT-PCR (Reverse Transcriptase Polymerase Chain Reaction)}

전체 리보핵산 [RNA, ribonucleic acid(total RNA)]은 TRIzol (Invitrogen, Grand Island, NY, USA)을 사용하면 서 $\mathrm{HaCaT}$ 세포로부터 분리하였다. 정제된 $\mathrm{RNA}$ 는 diethylpyrocarbonate로 처리된 물에 용해시킨 후 agarose-formaldehyde electrophoresis에 의해 그것의 순도 를 확인하였다. cDNA는 DNAse DNA-free (Ambion Inc., Austin, TX, USA)에 의해 전체 RNA로부터 합성하였다. 즉, RNA가 없는 DNA $1 \mu \mathrm{g}$ 은 oligodT 18 mer (bioneer, Daejeon, South Korea), RNAse OUT (Invitrogen, Grand Island, NY, USA), omniscript RT kit (Qiagene, Hilden, Germany)와 함께 $37^{\circ} \mathrm{C}$ 에서 60 분간 반응시켰다. 이때 사 용한 supplier는 다음과 같다.

MMP-1 증폭에 사용한 primers: MMP 1(521 bp, accession NM 002421) forward 5' -GGAGGGGATGCTCATTTTGATG-3' , reverse 5' -TAGGGAAGCCAAAGGAGCTGT-3' and GAPDH (446 bp, accession NM 2046.3) forward 5' -CAAAAGGGTCATCATCTCTG-3' , reverse 5' -CCTGCTTCACCACCTTCTTG-3' . 반응당 cDNA의 $1 \mu$ $\mathrm{L}$ 는 TopTaq Master Mix (Qiagen) 첨가에 의해 $20 \mu \mathrm{L}$ 의 부피로 조정되어졌다. 그 반응은 GeneAmp PCR System 9700(Applied Biosystems)에서 수행하였다. 그 증폭된 산 물들은 $\quad 1.2 \%$ Agarose gel에 전개되어졌고, Red safe(intron biotechnology, korea)에 의해 염색된 후 자외 선램프 아래에서 영상화하였다.

\subsection{Western blot}

세포는 단백질분해효소 저해제를 함유하는 완충용액 [50 mmol TrisHCl (pH 7.4), $150 \mathrm{mmol} \mathrm{NaCl}, 1 \mathrm{mmol}$ EDTA, $0.5 \%(\mathrm{v} / \mathrm{v})$ NP-40, $0.1 \%(\mathrm{w} / \mathrm{v})$ SDS, $1 \mathrm{mmol}$ EGTA, $100 \mu \mathrm{g} / \mathrm{mL}$ PMSF, $10 \mu \mathrm{g} / \mathrm{mL}$ pepstatin A, and 100 $\mu \mathrm{mol} \mathrm{Na} \mathrm{VO}_{3}$ ] $100 \mu \mathrm{L}$ 를 첨가하여 용해시켰다. 그 세포 lysate는 원심분리기 $12,000 \times \mathrm{g}, 4^{\circ} \mathrm{C}$ 에서 25 분간 원심분 리한 후 단백질 농도는 브래드포드 [Bradford reagent(Bio-Rad, Hercules, CA)] 방법을 사용하면서 결정 하였다. 단백질 $20 \quad \mu \mathrm{g}$ 은 sodium dodecyl sulfate-polyacrylamide gel electrophoresis (SDS-PAGE)에 서 $100 \mathrm{~V}, 90$ 분간 전개시켰다. 전개된 단백질들은 polyvinylidene difluoride 막 [PVDF membranes (Amersham Biosciences, Piscataway, NJ, USA)]에 옮겼 다. 막은 TBST 완충용액[10 mmol TrisHCl (pH 7.5), 150 $\mathrm{mmol} \mathrm{NaCl}, 0.1 \%$ (v/v) Tween-20]에 용해된 5\%(w/v) nonfat dry milk로 $4^{\circ} \mathrm{C}$ 에서 1 일간 blocking하고, 다음날 anti-MMP-1 (1:2000 dilution; MERCK)와 anti-GAPDH (1:3000, Santa Cruz Biotechnology, Santa Cruz, CA) 항체 를 혼합하여 $4^{\circ} \mathrm{C}$ 에서 1 일간 blocking하였다. 1차 항체를 제거한 후에 TBST 완충용액으로 실온에서 3 번 세척하 고, horseradish peroxidase (HRP)가 연결된 2차 마우스 항체[horseradish peroxidase (HRP)-conjugated secondary 
anti-mouse (1:2000 dilution; Santa Cruz Biotechnology)] 와 함께 실온에서 1 시간 반응시켰다. 그 막은 다시 TBST 완충용액으로 세척하고 면역반응 밴드 (immunoreactive bands)는 RAS-4000 mini (GE Healthcare Life Sciences) 에서 ECL 반응제 [ECL reagent (Amersham Pharmacia Biotech, Uppsala, Sweden)]를 사용하면서 확인하였다. 그 밀도 값 (Densitometric band values)은 이미지 분석 프로 그램 [image analysis software (National Institutes of Health)]에서 '이미지 J (image J)' 를 사용하면서 결정하 였다.

\subsection{ELISA (enzyme-linked immunosorbent assay)}

$\mathrm{HaCaT}$ 세포는 6-well plates에서 웰당 $2 \times 10^{5}$ 로 배양 한 후 tumor necrosis factor alpha (TNF-a) $10 \mathrm{ng} / \mathrm{mL}$ 를 미 리 처리한 후 $\mathrm{GA}$ 를 처리하였다. 24시간 후 세포 배양액 은 모아서 원심분리기에서 $10,000 \times \mathrm{g}, 5$ 분 동안 원심분 리 시켰다. 그 상등액 중의 MMP-1은 Fluorokine E Human Active MMP-1 Fluorescent Assay Kit (R\&D Systems)을 사용하면서 fluorescent assay에 의해 정량화 하였다.

\section{9 통계 처리}

모든 결과 값은 세 번의 독립적인 실험에 의해 얻어진 값들의 평균 \pm 표준편차로 나타내었다. 대조군과 실험군 사이의 통계학적 유의성 검정은 Tukey test를 사용하면서 ANOVA검정을 적용하였으며, $p<0.05$ 수준에서 유의성 검정을 실시하였다.

\section{3. 결과 및 고찰}

\section{1 목단피로부터 gallic acid의 분리}

목단피 에탄올 추출물로부터 ESI-MS, ${ }^{1} \mathrm{H}-\mathrm{NMR}$ 과 ${ }^{13} \mathrm{C}-\mathrm{NMR}$ 을 수행하여 얻어진 자료를 기존 문헌과 비교하 여 gallic acid (GA)를 동정하였다[Fig. 2][18].

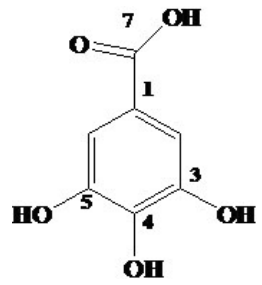

[Fig. 2] Structure of gallic acid

\subsection{Gallic acid의 세포독성 평가}

$\mathrm{GA}$ 를 저농도인 $6.25,12.5,25 \mu \mathrm{g} / \mathrm{mL}$ 로 처리시에는 살 아있는 세포가 거의 $100 \%$ 일 정도로 독성을 나타내지 않 았지만, $\mathrm{GA}$ 의 처리 농도가 $50 \mu \mathrm{g} / \mathrm{mL}$ 일 때 살아 있는 세 포는 약 $90 \%$ 를 나타내었으며, $100 \mu \mathrm{g} / \mathrm{mL}$ 로 처리시 $80 \%$ 정도의 세포를 유지하였다[Fig. 3]. 또한 GA의 처리 농도 가 $200 \mu \mathrm{g} / \mathrm{mL}$ 일 때 살아 있는 세포는 약 $79 \%$ 를 나타내 었다[Fig. 3]. 그러므로 $\mathrm{GA}$ 의 처리 농도가 높아짐에 따라 농도 의존적으로 살아 있는 세포수가 감소함을 알 수 있 었다.

선행 연구에서 GA는 HL-60 (human promyelocytic leukemia cells)세포에 대해 $300 \mu \mathrm{mol}$ 의 $\mathrm{IC}_{50}$ 값을 나타내 었고, A549 (carcinomic human alveolar basal epithelial) 세포에서는 100-200 $\mathrm{\mu mol}$ 의 $\mathrm{IC}_{50}$ 값을 나타내었다 $[19,20]$. 본 연구 결과에서 $\mathrm{HaCaT}$ 세포에서 $\mathrm{GA}$ 처리 농 도가 높아짐에 따라 농도 의존적으로 살아 있는 세포수 가 감소함을 알 수 있었다.

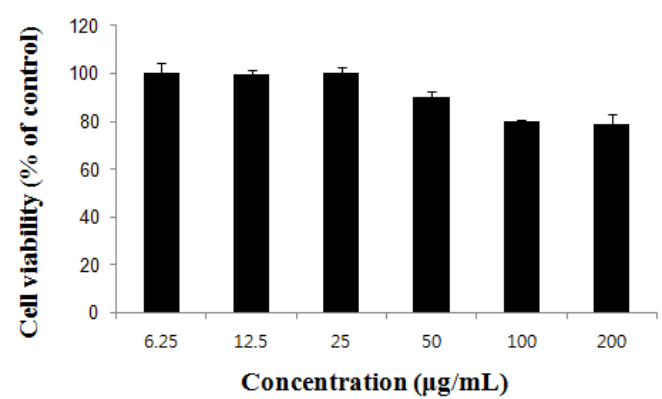

[Fig. 3] Cell viability of $\mathrm{HaCaT}$ cells treated with gallic acid. Gallic acid treated with concentration of $6.25,12.5,25,50,100$ and $200 \mu \mathrm{g} / \mathrm{mL}$ for 24 $\mathrm{h}$ and the cytotoxicity was measured by SRB assay. The data are displayed with mean \pm SD $(n=3)$.

\subsection{Gallic acid의 항산화 활성}

$\mathrm{GA}$ 는 $30 \mu \mathrm{g} / \mathrm{mL}$ 의 $\mathrm{IC}_{50}$ 과 함께 항산화능을 나타내었 고, 양성대조군인 $\mathrm{BHA}$ 는 $58 \mu \mathrm{g} / \mathrm{mL}$ 의 $\mathrm{IC}_{50}$ 을 나타내었 다[Table 1]. 따라서, $\mathrm{GA}$ 의 항산화능은 합성 항산화제인 $\mathrm{BHA}$ 보다 그 항산화능이 높음을 알 수 있었다.

[Table 1] Antioxidant activity of gallic acid.

\begin{tabular}{c|c}
\hline Compounds & $\begin{array}{l}\text { DPPH radical } \\
\left(\mathrm{IC}_{50}, \mu \mathrm{g} / \mathrm{mL}\right)\end{array}$ \\
\hline \hline Gallic acid & $30.0 \pm 2.4$ \\
\hline BHA & $58.0 \pm 3.6$ \\
\hline
\end{tabular}


Results are presented as the mean IC50 values obtained from three independent experiments carried out in triplicate \pm SD.

\subsection{TNF- $\alpha$ 로 유도된 $\mathrm{MMP}-1 \mathrm{mRNA}$ 에 대한 $\mathrm{GA}$ 의 영향}

$\mathrm{HaCaT}$ 세포에 TNF-a $(10 \mathrm{ng} / \mathrm{mL})$ 의 처리에 의한 자극 은 정상 세포의 MMP- $1 \mathrm{mRNA}$ 의 양에 비해 MMP- 1 의 수준을 유의적으로 증가시키는 것으로 나타났다 $(p<0.05$, Fig. 4). GA를 저농도인 $10 \mu \mathrm{g} / \mathrm{mL}$ 처리시 MMP-1 mRNA 의 양에는 큰 변화를 미치지 않는 것으로 나타났고, GA $20,50 \mu \mathrm{g} / \mathrm{mL}$ 의 농도 처리시 MMP-1의 mRNA는 약간 감 소하는 것으로 나타났다. 그러나 GA $100 \mu \mathrm{g} / \mathrm{mL}$ 의 농도 처리시 TNF-a의 자극에 의해 증가된 MMP- $1 \mathrm{mRNA}$ 는 TNF- $a$ 만 처리한 세포의 MMP- 1 mRNA의 양에 비해 유 의적으로 감소하는 것으로 나타났다 $(p<0.05)$. 따라서, $\mathrm{HaCaT}$ 세포에서 TNF-a $(10 \mathrm{ng} / \mathrm{mL})$ 의 처리에 의해 증가 된 $\mathrm{MMP}-1$ 은 $\mathrm{GA}$ 의 처리에 의해 농도 의존적으로 감소함 을 알 수 있었다.
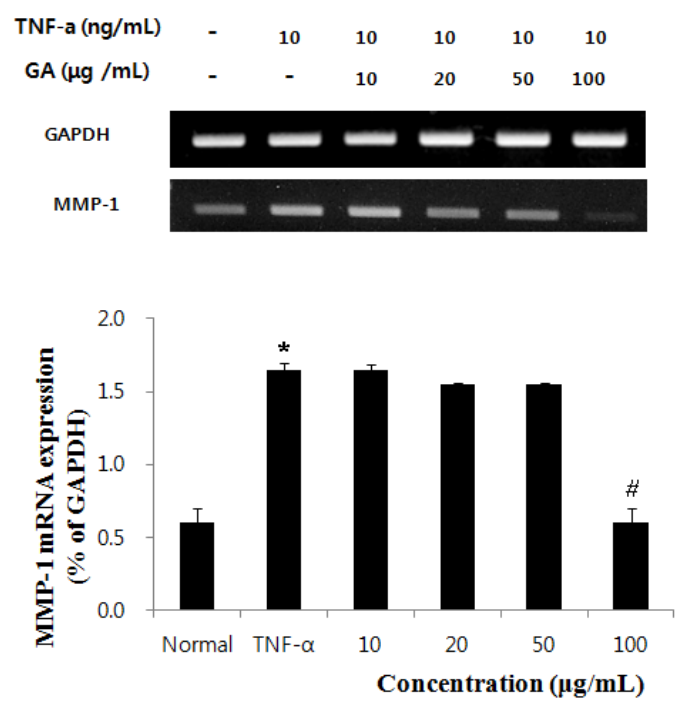

[Fig. 4] Effect of gallic aicd on TNF- $\alpha$-induced MMP-1 mRNA expressions in $\mathrm{HaCaT}$ cells. HaCaT cells were incubated with TNF- $\alpha(10 \mathrm{ng} / \mathrm{mL})$ in gallic acid. To investigate effect of gallic acid, cells were stimulated with TNF- $\alpha$ (10 ng/mL) and the indicated concentrations of gallic acid for $24 \mathrm{~h}$. Total cellular RNA was analyzed RT-PCR for MMP-1 and GAPDH. GAPDH was used as control. * Significantly different from normal $(p<0.05)$. \#Significantly different from TNF- $\alpha$ $(p<0.05)$.

\subsection{TNF- $\alpha$ 로 유도된 $\mathrm{MMP}-1$ 단백질 발현에 대한 $\mathrm{GA}$ 의 영향}

MMP-1 단백질 발현은 $\mathrm{HaCaT}$ 세포에서 TNF-a (10 $\mathrm{ng} / \mathrm{mL})$ 의 처리에 의해 유의적으로 증가되었다 $(p<0.05)$. $\mathrm{GA} 10 \mu \mathrm{g} / \mathrm{mL}$ 처리시 MMP-1 단백질 발현에는 큰 변화 를 미치지 않았지만, GA $20 \mu \mathrm{g} / \mathrm{mL}$ 처리시 MMP-1 단백 질 발현은 감소하였으며, $50,100 \mu \mathrm{g} / \mathrm{mL}$ 처리시 더 큰 감 소를 나타내었고, $\mathrm{HaCaT}$ 세포에서 TNF- $\mathrm{a}$ 만 처리한 세포 의 MMP-1 단백질 발현에 비해서 유의적으로 감소하였 다 $(p<0.05$, Fig. 5).

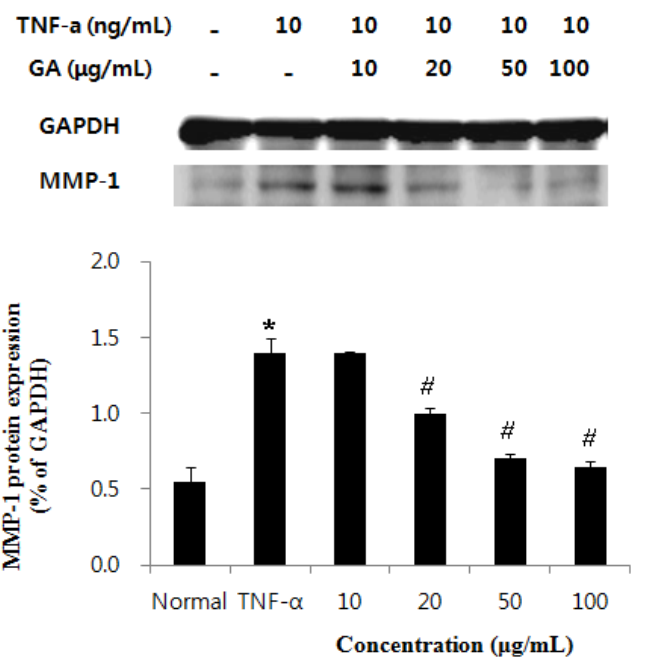

[Fig. 5] Effect of gallic aicd on TNF- $\alpha$-induced MMP-1 protein expressions in $\mathrm{HaCaT}$ cells. $\mathrm{HaCaT}$ cells were incubated with TNF- $\alpha \quad(10 \mathrm{ng} / \mathrm{mL})$ in gallic aicd. To investigate effect of ethanol extracts, cells were stimulated with TNF- $\alpha \quad(10 \mathrm{ng} / \mathrm{mL})$ and the indicated concentrations of nutmeat and husk extract for $24 \mathrm{~h}$. The cell lysates were analyzed by Western blotting with anti-MMP-1, anti-GAPDH. Anti-GAPDH was used as control. *Significantly different from normal $(p<0.05)$. \#Significantly different from TNF- $\alpha \quad(p<0.05)$.

\subsection{TNF- $\alpha$ 로 유도된 $\mathrm{MMP}-1$ 분비에 대한 $\mathrm{GA}$ 의 영향}

TNF-a $(10 \mathrm{ng} / \mathrm{mL})$ 의 처리에 의해 유도된 MMP-1 분 비 정도는 ELISA에 의해 분석하였다. 결과로써 $\mathrm{HaCaT}$ 세 포에 TNF-a(10 ng/mL)의 처리는 MMP- 1 의 분비를 정상 세포에 비해 유의적으로 증가되었다 $(p<0.05$, Fig. 6). GA 농도를 $10,20,50,100 \mu \mathrm{g} / \mathrm{mL}$ 으로 증가시킴에 따라 MMP-1 분비는 TNF- $a$ 만 처리한 세포에 비해서 유의적으 로 감소하였다 $(p<0.05$, Fig. 6). 


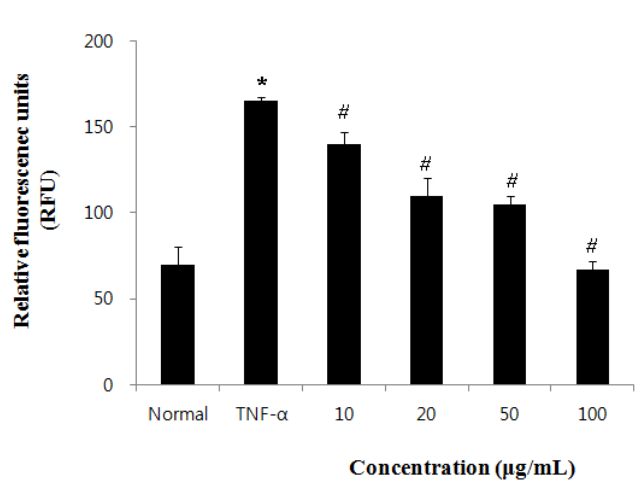

[Fig. 6] Inhibition of TNF- $\alpha$-induced MMP-1 secretion from $\mathrm{HaCaT}$ cells by gallic acid. Cells were stimulated with TNF- $\alpha$ (10 ng/mL) and the indicated concentrations of gallic acid for $24 \mathrm{~h}$. Level of MMP-1 in culture media was measured using a commercially available ELISA kit as described in Methods. *Significantly different from normal $(p<0.05)$. \#Significantly different from TNF- $\alpha(p<0.05)$.

선행 연구에서 주름 관련 유전자인 MMP-1 발현에 대 한 차가버섯 추출물의 영향을 연구한 결과 차가버섯 추 출물의 첨가가 MMP-1의 발현량을 감소시킴을 보고하였 다[2]. 또한 산거울 추출물이 MMP-1의 발현을 저해함을 보고하였다[21]. 본 연구에서도 GA는 MMP-1 mRNA, protein expression, secretion을 감소시킴으로써 주름개선 소재로서의 응용가능성을 확인하였다.

\section{4. 결론}

본 연구에서는 목단피 추출물로부터 항산화능을 갖는 $\mathrm{GA}$ 를 분리하였고, 그것의 MMP-1 저해 활성을 연구하였 다. 그 결과 $\mathrm{GA}$ 의 항산화능은 합성 항산화제인 $\mathrm{BHA}$ 보 다 높았으며, $\mathrm{HaCaT}$ 세포에서 농도 의존적으로 약한 세 포독성을 나타내었다. 또한 $\mathrm{GA}$ 는 $\mathrm{HaCaT}$ 세포에서 TNF$\mathrm{a}$ 의 처리에 의해 증가된 MMP-1 mRNA, protein expression, secretion을 농도 의존적으로 유의적인 감소를 나타내었다 $(p<0.05)$. 따라서 목단피로부터 분리한 $\mathrm{GA}$ 는 항산화 및 주름을 완화시킬 수 있다는 것을 확인하였으 며, 주름 개선제로써 활용 가능하리라 사료된다.

\section{References}

[1] B. A. Gilchrest, "Skin aging and photoaging : an overview," Journal of the American Academy of Dermatology, Vol. 21, No. 3, pp. 610-613, 1989. DOI: http://dx.doi.org/10.1016/S0190-9622(89)70227-9

[2] S. H. Lee, S. H. Park, K. H. Lee, S. J. Park, Y. H. Kim, "Effect of Inonotus obliquus Extract on the Expression MMPs and HAS-2," Journal of the Societic of Cosmetic Scientists Korea, Vol. 37, No. 3, pp. 237-245, 2011.

[3] L. Rittie, G. J. Fisher, "UV-light-inducde signal cascades and skin aging," Ageing Research Reviews, Vol. 1, No. 4, pp. 705-720, 2002.

DOI: http://dx.doi.org/10.1016/S1568-1637(02)00024-7

[4] J. M. Yoo, Y. J. Kang, H. B. Pyo, E. S. Choung, S. Y. Park, J. H. Choi, G. J. Han, C. H. Lee, T. J. Kim, "Anti-wrinkle effects of korean rice wine cake on human fibroblast," Journal of Life Sciences, Vol. 20, No. 12, pp. 1838-1843, 2010.

DOI: http://dx.doi.org/10.5352/JLS.2010.20.12.1838

[5] E. J. Kim, M. K. Kim, X. J. Jin, J. H. Oh, J. E. Kim, J. H. Chung, "Skin aging and photoaging alter fatty acids composition, including 11,14,17-eicosatrienoic acid, in the epidermis of human skin," Journal of the Korean Medical Science, Vol. 25, No. 6, pp. 980-983, 2010.

DOI: http://dx.doi.org/10.3346/jkms.2010.25.6.980

[6] K. J. Park, S. H. Park, J. K. Kim, "Anti-wrinkle activity of acanthopanax senticosus extract in ultraviolet B (UVB)-induced photoaging," Journal of the Korean Society Food Science and Nutrition, Vol. 39, No. 1, pp. 42-46, 2010.

DOI: http://dx.doi.org/10.3746/jkfn.2010.39.1.042

[7] K. Fraizer, S. Williams, D. Kothapal, H. Klapper, G. R. Grotendorst, "Stimulation of fibroblast cell-growth, matrix production, and granulation-tissue formation by connective-tissue growth-factor," Journal of Investigative Dermatology, Vol. 107, No. 3, pp. 404-411, 1996. DOI: http://dx.doi.org/10.1111/1523-1747.ep12363389

[8] P. Brenneisen, J, Oh, M. Wlaschek, J. Wenk, K. Briviba, C. Hommel, G. Herrmann, H. Sies, K. Scharffetter-Kochanek, "Ultraviolet B wavelength dependence for the regulation of two major matrix-metalloproteinases and their inhibitor TIMP-1 in human dermal fibroblasts," Photochemistry \& Photobiology, Vol. 64, No. 5, 877-885, 1996.

DOI: http://dx.doi.org/10.1111/j.1751-1097.1996.tb01851.x

[9] B. J. An, J. H. Kwak, J. M. Park, J. Y. Lee, T. S. Park, J. T. Lee, J. H. Son, C. Jo, M. W. Byun, "Inhibition of enzyme activities and the antiwrinkle effect of polyphenol isolated from the persimmon leaf (Diospyros 
kaki folium) on human skin." Dermatologic Surgery, Vol. 31, No. 7 Pt 2, pp. 848-854, 2005.

[10] E. Bauza, G. Oberto, A. Berghi, C. F. Dal, N. Domloge, "Collagen-like peptide exhibits a remarkable antiwrinkle effect on the skin when topically applied: in vivo study." International Journal of Tissue Reactions, Vol, 26, No. 3-4, pp. 105-11, 2004.

[11] P. L. Liao, C. H. Li, C. Y. Chang, S. R. Lu, C. H. Lin, L. S. Tse, Y. W. Cheng, "Anti-ageing effects of alpha-naphthoflavone on normal and UVB-irradiated human skin fibroblasts." Experimental Dermatology, Vol. 21, No. 7, pp. 546-548, 2012.

DOI: http://dx.doi.org/10.1111/j.1600-0625.2012.01517.x

[12] C.L. Hsieh, C. Y. Cheng, T. H. Tsai, I. H. Lin, C. H. Liu, S. Y. Chiang, J. G. Lin, C. J. Lao, N. Y. Tang, "Paeonol reduced erebral infarction involving the superoxide anion and microglia activation in ischemia-reperfusion injured rats," Journal of Ethnopharmacology, Vol. 106, No. 2, pp. 208-215, 2006.

DOI: http://dx.doi.org/10.1016/j.jep.2005.12.027

[13] Y. Li, W. Zhang, L. Huang, J. Shi, "Pharmacological of cortexmoutan and core," Zhongguo Zhong Yao Za Zhi, Vol. 22, No. 4, pp. 214-254, 1997.

[14] G. S. Oh, H. O. Pae, H. Oh, S. G. Hong, I. K. Kim, K. Y. Chai, Y. G. Yun, T. O. Kwon, H. T. Chung, "In vitro anti-proliferative effect of 1,2,3,4,6-penta-O-galloyl -beta-D-glucose on human hepatocellular carcinoma cell line, SK-HEP-1 cells," Cancer Letters, Vol. 174, No. 1, pp. 17-24, 2001

DOI: http://dx.doi.org/10.1016/S0304-3835(01)00680-2

[15] M. P. Sheehan, D. J. Atherton, "One-year follow up of children treated with Chinese medicinal herbs for atopic eczem," British Journal of Dermatology, Vol. 130, No. 4, pp. 488-493, 1994.

DOI: http://dx.doi.org/10.1111/j.1365-2133.1994.tb03383.x

[16] H. J. Choi, J. H. Song, K. S. Park, S. H. Baek, "In vitro anti-enterovirus 71 activity of gallic acid from Woodfordia fruticosa flowers," Letters in Applied Microbiology, Vol. 50, No. 4, pp. 438-440, 2010.

DOI: http://dx.doi.org/10.1111/j.1472-765X.2010.02805.x

[17] M. S. Blois, "Antioxidant determination by the use of a stable free radical," Nature, Vol. 181, No. 1, pp. 1199-1200, 1958.

DOI: http://dx.doi.org/10.1038/1811199a0

[18] G. Alessandria, S. Filippeschi, P. Sinibaldi, F. Mornet, P. Passera, F. Spreafico, P. M. Cappa, P. M. Gullino, "Influence of gangliosides on primary and metastatic neoplastic growth in human and murine cells," Cancer Research, Vol. 47, No. 16, pp. 4243-4247, 1987.

[19] O. Benavente-Garcia, J. Castillo, F. R. Marin, A. Ortuno, J. A. Del Rio, "Uses and properties of citrus flavonoids," Journal Agricultural and Food Chemistry, Vol. 45, No. 12, pp. 4505-4515, 1997.

DOI: http://dx.doi.org/10.1021/jf970373s

[20] J. Kim, H. Lee, Y. Lee, B. G. Oh, C. Cho, Y. Kim, M. Shin, M. Hong, S. K. Jung, H. Bae, "Inhibition effects of Moutan cortex Radicis on secrtion of eotaxin in A549 human epithelial cells and eosinophil migration," Journal of Ethnopharmacology, Vol. 114, No. 2, pp. 186-193, 2007.

DOI: http://dx.doi.org/10.1016/j.jep.2007.07.038

[21] S. H. Park, K. H. Lee, C. S. Han, K. H. Kim, Y. H. Kim, "Inhibitory effects of Carex humilis extract on elastase activity and matrix metalloproteinase-1 expression," Journal of the Societic of Cosmetic Scientists Korea, Vol. 36, No. 2, pp. 129-136, 2010.

\section{김 범 호(Pom-Ho Kim)}

[정회원]

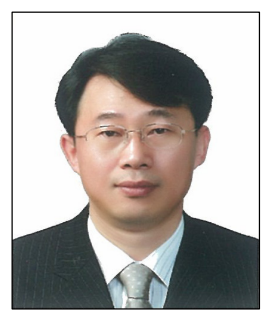

- 2013년 8월 : 원광대학교 한의학 전문대학원 한의학 박사

- 2012년 3월 현재 : 경운대학 교 보건바이오학부 강사

<관심분야>

전통의학, 자연의학, 건강증진 